\section{Animal lib and racial bigotry}

SIR - David Wolpert ${ }^{1}$ equates animal research with racial bigotry. But the rhetoric of animal rights groups, particularly antivivisectionists, is disturbingly similar to the rhetoric of groups that promote racial violence.

At the centre of antivivisectionism is a core of extreme cynicism and paranoia. Antivivisectionists generally hold that all animal research is meaningless or actually harmful. How can they account for the vast amount of animal research? Their explanation is a vast conspiracy of 'science', 'mass media', 'industry' that actually creates 'new diseases'3. Such global conspiracy theories have always appealed to frightened, alienated and uneducated people looking for simple answers. This cynicism is also the root of the destructive nihilism of the terrorist. Burroughs noted: "where nothing is true ... therefore everything is permitted"3. The ritualization of cynicism and paranoia is the major theme extending from the ancient Assassin cult $^{3,4}$, to the Nazi party ${ }^{5}$, to the genocidal Khmer Rouge ${ }^{4,6}$.

Belief in conspiracy alone is not sinister, but although animal rightists start with the laudable goal of making the treatment of animals more humane, they more often succeed only in dehumanizing other people, especially scientists. This may account for the large number of animal rights activists endorsing vandalism or violence ${ }^{6}$, and the attempted assassination of researchers in England ${ }^{7}$.

Antivivisectionism is also a cult of superiority. Its supporters proclaim themselves to be healthier, morally superior and smarter than any group in human history. With such impressive credentials, they could be considered the new master race.

Antivivisectionists are also contemptuous of the sick. They would end most medical research, because the only reason for being sick is having the wrong lifestyle. This blame-the-victim viewpoint exploits the very real prejudice against people with chronic diseases such as AIDS and even people who have recovered from cancer. Apparently the bright utopia envisaged by the animal rights people will not include those with genetic problems, birth defects and chronic or degenerative diseases. Perhaps the death of these sick people would be the final solution.

Who supports animal research? Wolpert implies a financial motive by stating "No [scientists] are as incensed by the animal rights movement as those whose careers it threatens." I would suggest that the most incensed people are those who feel that the lives of their family members are directly threatened by the animal rights movement. As a scientist, I understand how animal research was essential for the treatment of my mother's congenital kidney disease, my father's neurosurgery, my best friend's bone marrow transplant and treatment of my classmate's type I diabetes. Perhaps if animal rights activists got out more and volunteered to work with the chronically ill, it might broaden their outlook.

\section{Evans Trail, Apt 201,}

\section{Beltsville, Maryland 20705, USA}

1. Wolpert, D. Nature 352, 466 (1991)

2. Handbill- Animal Liberation Network, Hunt Valley, Mary land, USA.

3. Burroughs, W. S. The Cities of the Red Night (Holt, Rinehart and Winston, 1981).

4. Morrow, L. Time 137 no. 23, 48-53. (1990).

5. Fromm, E. Escape From Freedom (Avon Books, 1941)

6. Storr, A. Human Destructiveness (Grove Weidenfeld, New York, 1991)

7. Holden, C. Science 253, 264 (1991)

8. Cherfas, J. Science 248, 1485 (1990)

SIR - Your report (Nature 353, 687; 1991) on the settlement reached by Katie McCabe and Alex Pacheco and the People for the Ethical Treatment of Animals (PETA) in the suit brought against McCabe for her article "Beyond Cruelty" in the Washingtonian prompts me to comment on the clarifications and corrections of the article that the Washingtonian published. As the magazine stated in an earlier press release, McCabe “. . . was right on the main ideas, which should continue to be written about".

I believe her article still stands as a powerful indictment of the animal rights movement. In fact, two of the corrections seem to indicate that Alex Pacheco had more interest in using the wellknown Silver Spring monkeys as political tools than in caring for them. Although McCabe could not prove that Pacheco had staged a particular photograph of a monkey in a restraining device in Taub's laboratory, it is evident that Pacheco took a picture rather than adjusting the head restraint for the monkey so as to relieve its discomfort.

Similarly, although McCabe could not prove that other photographs (not mentioned in your article) showing uncleaned fecal pans were staged, or that Pacheco himself let laboratory conditions deteriorate in Taub's absence, Pacheco damns himself when he claims he did not clean because "it was not his duty to do so". When animal caretakers are absent, any ordinary researcher knows it becomes his duty.

Still unchallenged is McCabe's most serious charge, that "the only incontrovertible act of animal cruelty was perpetrated by PETA. The three PETA members into whose custody police placed the [Silver Spring] monkeys trans- ported them 2,000 miles to Florida by truck. After their court-ordered return to Taub, elevated white-blood-cell counts indicated severe stress, and a veterinarian described them as 'one of the most withdrawn and depressed' groups of animals he had ever seen."

The bulk of McCabe's article rightly portrayed a nightmarish outlook - if animal rights organizations prevail in winning their stated objectives - where men, women and children afflicted with diseases for which we now have no treatment or cure will have little hope of ever getting well.

That may be the world PETA wants, but it is not the world wanted by researchers and clinicians devoted to helping people live healthier lives. It is hard to believe that anyone is against doing all we can to help the autistic child caught in his or her silent world, to defeat schizophrenia, to find a vaccine for AIDS, to develop new operations for congenital defects or to realize other key steps that will make the lives of many of our citizens healthier and happier.

FREDERICK K. GOODWIN

(Administrator)

Alcohol, Drug Abuse, and

Mental Health Administration,

Rockville,

Maryland 20857, USA

\section{Analytical language}

SIR - J. R. Smythies (Nature 355, 490; 1992) is perhaps too readily dismissive of the belief - held, he says, by many philosophers - that linguistic or logical analysis can contribute to the solution of problems relating to mind and perception. Only observation, hypothesis and experiment can do this, he believes, and I would not wish to challenge this.

But surely observation and analysis of the structure of language, that unique and most complex mode of human behaviour, may tell us something about the structure of the brain and how it functions.

The way the brain is apparently constrained to think (and speak), as reflected in the deep structure of human language, may lead to some understanding of the way the brain is (or is not) wired up and programmed.

Such an understanding may say something about how the brain handles perception and even about the relationship of these neural activities to self-consciousness and the mind. This kind of linguistic analysis would not constitute a poetic approach to cognitive neuroscience, though it was not, of course, Wittgenstein's way.

R. M. FRY

PO Box 387

Bondi Junction, NSW 2202,

Australia 